\title{
IgG4-related disease and systemic vasculitis - is there any connection?
}

\section{Choroba IgG4-zależna a układowe zapalenie naczyń - czy istnieje jakiś związek?}

\author{
Anna Masiak, Zbigniew Zdrojewski \\ Department of Internal Medicine, Connective Tissue Diseases and Geriatrics, Medical University of Gdańsk
}

Key words: IgG4-related diseases, systemic vasculitis, ANCA antibody.

Słowa kluczowe: choroba IgG4-zależna, układowe zapalenie naczyń, przeciwciała ANCA.

\begin{abstract}
Sum mary
IgG4-related disease is a relatively new group of diseases of still unknown etiology. It is characterized by elevated serum levels of subclass IgG4 immunoglobulin and by abundant infiltration of IgG4+ plasma cells with typical fibrosis of the affected organs. Elevated concentration of lgG4 may be present in many other conditions associated with chronic inflammation. In recent years, it is noted that this may also apply to patients with systemic vasculitis, in particular antineutrophil cytoplasmic antibody (ANCA)-associated vasculitis. The aim of this study is to draw attention to the fact that in some cases, both clinical presentation and histopathological findings in IgG4-related diseases and systemic vasculitis may be similar. The importance of elevated serum IgG4 immunoglobulin in patients with ANCA-associated vasculitis (AAV) is unclear and requires further research.
\end{abstract}

\section{Introduction}

IgG4-related disease (IgG4-RD) is a relatively new and still not fully understood group of diseases [1, 2]. It is characterised by elevated serum concentrations of the IgG4 subclass of immunoglobulins and typical histopathological features (tissue infiltration by lgG4-positive cells, a cartwheel-like pattern of fibrosis (storiform fibrosis), and obliterative phlebitis) [2-5].

The pathogenesis of the disease remains unclear. Autoimmune and allergic factors are being considered $[6,7]$. The $\mathrm{G} 4$ subclass (IgG4) is the rarest of the immunoglobulin subclasses. Its structure and properties are unique [8]. It possesses anti-inflammatory activity. The lgG4 subclass is also the only subclass incapable of ac-

\section{Streszczenie}

Choroby IgG4-zależne to stosunkowo nowa grupa schorzeń o niewyjaśnionej dotychczas etiologii. Charakteryzują się one zwiększonym stężeniem podklasy lgG4 immunoglobulin w surowicy i naciekami tkankowymi z komórek IgG4-dodatnich z typowym włóknieniem zajętych narządów. Zwiększone stężenie IgG4 może występować w wielu innych chorobach przebiegających z przewlekłym stanem zapalnym. W ostatnich latach zwraca się uwagę, że może to dotyczyć również chorych na układowe zapalenia naczyń, szczególnie ANCA-dodatnie. Celem niniejszego opracowania jest chęć zwrócenia uwagi na fakt, iż w niektórych przypadkach zarówno objawy kliniczne, jak i obraz histopatologiczny chorób IgG4-zależnych i układowych zapaleń naczyń mogą być podobne. Znaczenie zwiększonego stężenia lgG4 u chorych z AAV (ANCA-associated vasculitis) jest niejasne i wymaga dalszych badań.

tivating the classic complement pathway. It does, however, display an ability to bind with the Fc fragment of another IgG immunoglobulin. Mice models have demonstrated that subclasses exhibiting no complement activation ability may interact with other IgG antibody subclasses and activate the complement system via the lectin pathway [9]. What is known is that Th2-dependent cytokine activity, such as interleukin 4, 5, 10 and 13 as well as transforming growth factor $\beta$ (TGF- $\beta$ ), elicits a response in the form of eosinophilia, elevated concentrations of IgG4 and IgE, and progressive fibrosis [8]. The results of studies conducted to date have shown that it is overexpression of Th2 and Treg lymphocytes and their dependent cytokines that plays the main role in the pathogenesis of IgG4-related disease [10-12]. These

Address for correspondence:

Anna Masiak, MD, PhD, Department of Internal Medicine, Connective Tissue Diseases and Geriatrics, Medical University of Gdańsk, Dębinki 7, 80-211 Gdańsk, e-mail: anna.masiak@wp.pl

Submitted: 18.08.2014 
cytokines, primarily interleukin (IL)-10, are responsible for the appearance of allergic symptoms, eosinophilia and elevated concentrations of lgE and lgG4 - typical for IgG4-related disease [13].

IgG4-RD most commonly affects middle-aged and elderly men (mean age - 65 years) $[6,14-16]$. Onset of the disease is usually sub-acute with an absence of systemic symptoms, and diagnosis is often incidental. The disease process usually involves multiple organs and leads to progressive organ fibrosis and decreased function. The most commonly affected sites are the pancreas, hepatic bile duct, salivary glands, soft tissues of the orbital cavity, and lymph nodes. Less common sites include the mediastinum, retroperitoneal space, soft tissues, skin, central nervous system, thyroid, respiratory tract, kidneys, prostate, and the mammary gland $[2,6]$. Symptoms of the disease may present concurrently or develop metachronously. Over time, usually after a period of several years, the disease progresses to involve new organs, and new symptoms appear. In 2012, Japanese researchers proposed a set of criteria for the diag nosis of IgG4-related diseases (Table I) [6].

\section{IgG4-related disease and vasculitis}

Blood vessels of various calibre may also be affected in the course of IgG4-related disease [5, 17, 18]. Clinical similarities between IgG4-related disease and small-vessel vasculitis, particularly ANCA-positive vasculitis (ANCA-associated vasculitis - AAV]) are especially interesting [19]. Symptoms of asthma, involvement of the paranasal sinuses, lungs, kidneys and peripheral eosinophilia are common to both conditions. Publications have described cases of IgG4-related disease with concomitant cutaneous leukocytoclastic vasculitis [20], Henoch-Schönlein purpura [21], or allergic vasculitis with hypocomplementaemia [22].

A noteworthy feature is that some patients with AAV have elevated serum IgG4 concentrations and IgG4+ cell infiltration of affected tissues. Elevated serum IgG4 subclass concentrations are present in most patients diagnosed with IgG4-related disease. It is worth bearing in mind that physiological lgG4 responses may be initiated by repeated exposure to an antigen, and elevated concentrations of IgG4 are also present in chronic inflammation, neoplasms, autoimmune diseases, infections, and vasculitis [23, 24].

Of 158 patients hospitalized at the Mayo Clinic, found to have elevated serum IgG4 subclass concentrations (> $140 \mathrm{mg} / \mathrm{dl}$ ), only 29 patients (18.4\%) fullfiled the criteria for definite or probable IgG4-related disease. At the same time, 9 patients (5.7\%) were diagnosed with vasculitis, 5 of whom had granulomatosis with polyangiitis
(GPA), 3 had eosinophilic granulomatosis with polyangiitis (EGPA), and 1 patient had polyarteritis nodosa [25]. Similarly, a study conducted by a French centre showed that only $10 \%$ of patients with elevated IgG4 concentrations were diagnosed with IgG4-related disease. In this study, 2 of the patients were diagnosed with vasculitis: microscopic polyangiitis (MPA) and cryoglobulinaemia in association with HCV infection [26]. A study by Carruthers et al. determined that the negative predictive value of an elevated IgG4 concentration was $96 \%$ and the positive predictive value was 34\% [27].

The largest number of reports of elevated serum IgG4 concentrations in patients with AAV concerns patients diagnosed with EGPA $[28,29]$. In a comparison of serum IgG4 concentrations in patients with EGPA, GPA and atopic asthma, Vaglio found that $75 \%$ of patients with active EGPA had an elevated level of IgG4. Serum IgG4 levels were significantly higher in patients with EGPA compared to patients with GPA or asthma, and IgG4 concentrations among patients with GPA were higher compared to healthy individuals. In patients with EGPA, serum IgG4 concentration correlated with disease activity assessed using the Birmingham Vasculitis Activity Score (BVAS), the number of affected organs and risk factors assessed by the Five Factors Score (FFS); at the same time, IgG4 levels declined during periods of remission [30]. Further research is needed in order to confirm the usefulness of repeated IgG4 determinations in monitoring therapy.

\section{Histopathological features}

A number of similarities between IgG4-related disease and AAV are also visible in microscopy images. Abundant inflammatory cell infiltration, focal areas of fibrosis and vascular lesions are characteristic morphological features of both conditions. This is particularly evident in biopsy material from the head and neck ar-

Table I. Clinical diagnostic criteria for IgG4-related disease according to Umehara et al. [6]

\begin{tabular}{|c|l|}
\hline 1. & $\begin{array}{l}\text { Characteristic features of organ involvement in the } \\
\text { form of diffuse or nodular enlargement or abnor- } \\
\text { mal organ function }\end{array}$ \\
\hline 2. & Elevated serum IgG4 concentration $(\geq 135 \mathrm{mg} / \mathrm{dl})$ \\
\hline 3. & $\begin{array}{l}\text { Histopathological abnormalities: } \\
(\text { A) lymphocyte and plasma cell infiltration and } \\
\text { fibrosis } \\
(B) \text { IgG4+ cell infiltration: }>10 \text { IgG4+ cells per high } \\
\text { power field and IgG4+/IgG cell ratio }>40 \%\end{array}$ \\
\hline & \multicolumn{1}{|c|}{ IgG4-related disease diagnosis: } \\
\hline Definite & $1+2+3$ \\
\hline Probable & $1+3$ \\
\hline Possible & $1+2$ \\
\hline
\end{tabular}


Table II. Differences between ANCA-positive vasculitis and IgG4-related disease (drawn up according to [19])

\begin{tabular}{|lcc|}
\hline \multicolumn{1}{|c|}{ Differentiating feature } & IgG4-RD & AAV \\
\hline ANCA antibodies & not found & present \\
\hline histopathological examination abnormalities & $\begin{array}{c}\text { Tissue infiltration by IgG4+ cells, } \\
\text { storiform fibrosis, } \\
\text { obliterative phlebitis }\end{array}$ & $\begin{array}{c}\text { necrotizing small-vessel } \\
\text { vasculitis, granulomas }\end{array}$ \\
\hline lgG4+ cell infiltration in affected organs/tissues & $>50$ cells per high power field & varied, lower \\
\hline lgG4+/lgG ratio & $>40 \%$ & varied, lower \\
\hline
\end{tabular}

eas. Necrotizing vasculitis and granulomas, typical features of AAV, are less common in these areas [31].

Researchers from the Mayo Clinic examined biopsy material obtained from patients with GPA and determined that lgG4+ cell infiltration was present in over $18 \%$ of these patients. An interesting point is that these infiltrations were only present in bioptates obtained from the upper respiratory tract and orbital tissues (38.1\%). They were not found in any other location or in any subject in the control group [32]. From a clinical perspective, this is a very significant observation, indicating that care must be taken when interpreting the results of histopathological examinations and their value in the context of the complete clinical picture. Determining the exact significance of IgG4+ cell infiltrates in the pathogenesis of GPA will require further studies. Some authors have suggested that significantly increased infiltration at these sites is linked to the intensity of inflammation [5]. Lacrimal and salivary gland inflammation leads to the activation of significant numbers of lymph nodules engaged in local IgG4+ cell production. The most important features that differentiate IgG4-related disease from ANCA-positive vasculitis are presented in Table II.

\section{ANCA antibody subclasses}

Antineutrophil cytoplasmic antibodies (ANCA) typically belong to the IgG class. Brouwer was the first to demonstrate that both PR3-ANCA and MPO-ANCA, present in a group of patients with $\mathrm{AAV}$, belonged predominantly to the IgG1 and IgG4 subclasses [33]. Many researchers have suggested that a subclass of these antibodies may be involved in the pathogenesis of AAV [34]. Studies have also indicated that ANCA-IgG4 plays an important role in GPA pathogenesis [35-37]. Elevated titres of the MPO-IgG4 subclass in patients with GPA may indicate repeated, chronic stimulation of the immune system [36]. At the same time, many studies have shown that the IgG3 subclass of PR3-ANCA is most closely associated with active disease and renal involvement $[34,35,38]$. However, defining the precise role of the IgG4 subclass of ANCA in the pathogenesis of AAV requires further research.

\section{Conclusions}

The association between IgG4-related disease and systemic vasculitis remains unclear. EGPA would appear to be the exception, where overexpression of Th2 lymphocytes and their related cytokines may explain the pronounced IgG4 response. Further studies are required to establish whether elevated IgG4 concentrations in inflammatory vascular disease play a significant role in its pathogenesis or are merely an incidental finding. In clinical practice, the possibility of clinical overlap of these two conditions should be borne in mind.

The authors declare no conflict of interest.

\section{References}

1. Khosroshahi A, Stone JH. A clinical overview of IgG4-related systemic disease. Curr Opin Rheumatol 2011; 23: 57-66.

2. Stone JH, Khosroshahi A, Deshpande V, et al. Recommendations for the Nomenclature of IgG4-related disease and its individual organ system manifestations. Arthritis Rheum 2012; 64: 3061-3067.

3. Stone JH, Zen Y, Deshpande V. IgG4-related disease. N Engl J Med 2012; 366: 539-551.

4. Deshpande V, Zen Y, Chan JK, et al. Consensus statement on the pathology of IgG4-related disease. Mod Pathol 2012; 25 : 1181-1192.

5. Zen Y, Nakanuma Y. IgG4-related disease: a cross sectional study of 114 cases. Am J Surg Pathol 2010; 34: 1812-1819.

6. Umehara H, Okazaki K, Masaki Y, et al. Comprehensive diagnostic criteria for IgG4-realted disease (IgG4-RD), 2011. Mod Rheumatol 2012; 22: 21-30.

7. Sato Y, Notohara K, Kojima M, et al. IgG4-related disease: historical overview and pathology of hematological disorders. Pathol Int 2010; 60: 247-258.

8. Aalberse RC, Stapel SO, Schuurman J, Rispens T. Immunoglobulin G4: an odd antibody. Clin Exp Allergy 2009; 39: 469-477.

9. Murata K, Fox-Talbot K, Qian Z, et al. Synergistic deposition of C4d by complement-activating and non-activating antibodies in cardiac transplants. Am J Transplant 2007; 7: 2605-2614.

10. Della Torre E, Mattoo H, Mahajan VS, et al. Prevalence of atopy, eosinophilia, and IgE elevation in IgG4-related disease. Allergy 2014; 69: 269-272. 
11. Kanari H, Kagami S, Kashiwakuma D, et al. Role of Th2 cells in IgG4-related lacrimal gland enlargement. Int Arch Allergy Immunol 2010; 152 Suppl 1: 47-53.

12. Suzuki K, Tamaru J, Okuyama A, et al. IgG-4 positive multiorgan lymphoproliferative syndrome manifesting as chronic symmetrical sclerosing dacryo-sialadenitis with subsequent secondary portal hypertension and remarkable IgG4-linked IL-4 elevation. Rheumatology (Oxford) 2010; 49: 1789-1791.

13. Kamisawa T, Anjiki H, Egawa N, Kubota N. Allergic manifestations in autoimmune pancreatitis. Eur J Gastroenterol Hepato 2009; 21: 1136-1139.

14. Kawano M, Saeki T, Nakashima H, et al. Proposal for diagnostic criteria for IgG4-related kidney disease. Clin Exp Nephrol 2011; 15: 615-626.

15. Raissian Y, Nasr SH, Larsen CP, et al. Diagnosis of IgG4-related tubulointerstitial nephritis. J Am Soc Nephrol 2011; 22: 13431352.

16. Alexander MP, Larsen CP, Gibson IW, et al. Membranous glomerulonephritis is a manifestation of IgG4-related disease. Kidney Int 2013; 83: 455-462.

17. Stone JR. Aortitis, periaortitis, and retroperitoneal fibrosis, as manifestations of IgG4-related systemic disease. Curr Opin Rheumatol 2011; 23: 88-94.

18. Kasashima S, Zen Y. IgG4-related inflammatory abdominal aortic aneurysm. Curr Opin Rheumatol 2011; 23: 18-23.

19. Perez Alamino R, Martínez C, Espinoza LR. IgG4-associated vasculitis. Curr Rheumatol Rep 2013; 15: 348.

20. Kawakami T, Yamaguchi N, Soma Y, et al. Immunoglobulin G4-related disease associated with cutaneous vasculitis. Acta Derm Venereol 2014; 94: 327-328.

21. Tamai R, Hasegawa Y, Hisano S, et al. A case of IgG4-related tubulointerstitial nephritis concurrent with Henoch-Schönlein purpura nephritis. Allergy Asthma Clin Immunol 2011; 7: 5.

22. Wakamatsu R, Watanabe H, Suzuki K, et al. Hypocomplementemic urticarial vasculitis syndrome is associated with high levels of serum IgG4: a clinical manifestation that mimics IgG4-related disease. Intern Med 2011; 50: 1109-1112.

23. Strehl JD, Hartmann A, Agaimy A. Numerous IgG4-positive plasma cells are ubiquitous in diverse localised non-specific chronic inflammatory conditions and need to be distinguished from IgG4-related systemic disorders. J Clin Pathol 2011; 64: 237-243.

24. Yamamoto M, Tabeya T, Naishiro Y, et al. Value of serum IgG4 in the diagnosis of IgG4-related disease and in differentiation from rheumatic diseases and other diseases. Mod Rheumatol 2012; 22: 419-425.

25. Ryu JH, Horie R, Sekiguchi $H$, et al. Spectrum of disorders associated with elevated serum IgG4 levels in clinical practice. Int J Rheumatol 2012; 2012: 232960

26. Ebbo M, Grados A, Bernit E, et al. Pathologies associated with serum IgG4 elevation. Int J Rheumatol 2012; 2012: 602809.

27. Carruthers MN, Khosroshahi A, Augustin T, et al. The diagnostic utility of serum IgG4 concentrations in IgG4-related disease. Ann Rheum Dis 2014, Mar 20 [Epub ahead of print].

28. Yamamoto $M$, Takahashi $H$, Suzuki $C$, et al. Analysis of serum IgG subclasses in Churg-Strauss syndrome: the meaning of elevated serum levels of IgG4. Intern Med 2010; 49: 13651370.
29. Ayuzawa N, Ubara Y, Keiichi S, et al. Churg-Strauss syndrome with a clinical condition similar to IgG4-related kidney disease: a case report. Intern Med 2012; 51: 1233-1238.

30. Vaglio A, Strehl JD, Manger B, et al. IgG4 immune response in Churg-Strauss syndrome. Ann Rheum Dis 2012; 71: 390-393.

31. Devaney KO, Travis WD, Hoffman G, et al. Interpretation of head and neck biopsies in Wegener's granulomatosis. A pathologic study of 126 biopsies in 70 patients. Am J Surg Pathol 1990; 14: 555-564.

32. Chang SY, Keogh KA, Lewis JE, et al. IgG4-positive plasma cells in granulomatosis with polyangiitis (Wegener's): a clinicopathologic and immunohistochemical study on 43 granulomatosis with polyangiitis and 20 control cases. Hum Pathol 2013; 44: 2432-2437.

33. Brouwer E, Tervaert JW, Horst G, et al. Predominance of IgG1 and IgG4 subclasses of antineutrophil cytoplasmatic autoantibodies (ANCA) in patients with Wegener's granulomatosis and clinically related disorders. Clin Exp Immunol 1991; 83: 379-386.

34. Colman R, Hussain A, Goodall M, et al. Chimeric antibodies to proteinase 3 of $\operatorname{lgG} 1$ and IgG3 subclasses induce different magnitudes of functional responses in neutrophils. Ann Rheum Dis 2007; 66: 676-682.

35. Holland $M$, Hewins P, Goodall $M$, et al. Anti-neutrophil cytoplasm antibody IgG subclasses in Wegener's granulomatosis: a possible pathogenic role for the IgG4 subclass. Clin Exp Immunol 2004; 138: 183-192.

36. Liu LJ, Chen M, Yu F, et al. IgG subclass distribution, affinity of anti-myeloperoxidase antibodies in sera from patients with Wegener's granulomatosis and microscopic polyangiitis. Nephrology 2008; 13: 629-635.

37. Hussain A, Pankhurst T, Goodall $M$, et al. Chimeric IgG4 PR3-ANCA induces selective inflammatory responses from neutrophils through engagement of Fc receptors. Immunology 2009; 128: 236-244

38. Pankhurst T, Nash G, Williams J, et al. Immunoglobulin subclass determines ability of immunoglobulin (Ig)G to capture and activate neutrophils presented as normal human IgG or disease-associated anti-neutrophil cytoplasm antibody (ANCA)-IgG. Clin Exp Immunol 2011; 164: 218-226. 